\title{
PENGEMBANGAN PERANGKAT PEMBELAJARAN KETERAMPILAN GENERIK KOMUNIKASI NEGOSIASI SISWA SMK DENGAN METODE 4-D
}

\author{
Siti Mazizatuz Zahroh \\ Program Studi Pendidikan Teknologi \& Kejuruan PP, UNY \\ siti.azizatus@gmail.com \\ Putu Sudira \\ Universitas Negeri Yogyakarta \\ putupanji@uny.ac.id
}

Abstrak

Penelitian ini bertujuan untuk mendeskripsikan, mengembangkan dan menghasilkan perangkat pembelajaran yang mampu melatihkan keterampilan generik komunikasi bernegosiasi siswa SMK dengan menggunakan metode $4 D$. Penelitian R\&D ini dilaksanakan di SMKN 4 Surakarta yaitu pada siswa kelas X Program Keahlian Tata Busana. Tahapan pengembangan perangkat terdiri dari empat fase yaitu define, design, develop, dan disseminate. Tahap define mencakup kegiatan studi pustaka dan survey lapangan untuk keperluan identifikasi masalah dan need analysis, tahap design mencakup kegiatan perancangan produk awal, tahap develop mencakup kegiatan validasi pakar, revisi produk, ujicoba satu-satu dan kelompok kecil, sedangkan tahap disseminate mencakup kegiatan sosialisasi lapangan dan revisi produk akhir. Teknik pengumpulan data yang digunakan adalah teknik observasi, wawancara, dokumentasi, dan angket. Analisis data menggunakan teknik analisis deskriptif secara kuantitatif dan kualitatif. Hasil penelitian menunjukkan: (1) metode $4 D$ merupakan metode yang fisibel dan efektif untuk digunakan dalam mengembangkan perangkat pembelajaran keterampilan generik komunikasi bernegosiasi; dan (2) perangkat pembelajaran yang dihasilkan mampu mengajarkan dan melatih keterampilan generik komunikasi bernegosiasi siswa kelas X SMKN 4 Surakarta.

Kata kunci: perangkat pembelajaran, keterampilan generik komunikasi, negosiasi.

\section{THE TEACHING DEVICES DEVELOPMENT OF GENERIC NEGOTIATION COMMUNICATION SKILL OF SMK STUDENTS USING 4D METHOD}

\begin{abstract}
The study aims to describe, develop and produce teaching devices which will be able to teach and train the generic negotiation communication skills of SMK students using 4D methods. This study is carried out in SMK 4 Surakarta class X Fashion Design Study Program. The stages of development consist of four phases, namely the define, design, development, and dissemination. Define phase includes the activities of literature studies and field surveys for the purposes of identification of the problem and need analysis. Design phase includes the initial product design activities. Develop stage includes expert validation activities, product revision, one to one evaluation and small groups evaluation. Field disseminate phase include socialization and revision of the final product. The data collection techniques are observation, interviews, documentation, and questionnaires. The data analyses techniques use descriptive quantitative and qualitative analysis techniques. The results show: (1) 4D method is feasible and effective in developing the teaching devices of negotiation generic skills; and (2) the resulting teaching devices are able to teach and train the generic communication skills to negotiate class X SMK 4 Surakarta.
\end{abstract}

Keywords: learning device, the generic communication skills, negotiation. 


\section{PENDAHULUAN}

Mempersiapkan perangkat pembelajaran di SMK harus menekankan pada keterampilan proses dan hasil atau output yang diinginkan yaitu yang menekankan pada etos kerja dan budaya industri, oleh karena itu kebiasaan ini harus ditanamkan sejak awal supaya terjadi internalisasi pada peserta didik. Adapun ke-biasaan kerja yang harus ditanamkan antara lain meliputi: disiplin, rajin, tekun, motivasi kerja tinggi pemecahan masalah, kerjasama, komunikasi yang baik, tanggung jawab. Kebiasaan ini bersifat personality atau karakter/kepribadian. Oleh karena itu, mereka (peserta didik) harus dibekali dengan berbagai macam kecerdasan, yang mencakup kecerdasan intelektual, emosional, sosial dan spiritual.

Ada dua kompetensi yang harus dikuasai oleh lulusan SMK yaitu keterampilan yang bersifat teknis atau hard skill dan keterampilan yang bersifat non teknis atau keterampilan generik. Dengan kata lain lulusan tidak hanya mempunyai kemampuan bekerja di bidangnya (keterampilan teknis) tetapi ia juga harus memiliki kemampuan menghadapi perubahan dan dapat memanfaatkan perubahan itu. Kemampuan ini merupakan kemampuan atau keterampilan generik.

Senada dengan hal di atas, Cairney (Suarta, 2012, p.2) mengungkapkan: selain memiliki keterampilan teknis di bidangnya, dunia kerja/ industri saat ini sangat membutuhkan pekerja yang memiliki keterampilan yang bersifat generik (employability skills). Keterampilan komunikasi dan keterampilan berpikir tingkat tinggi seperti pengambilan keputusan, pemecahan masalah, fleksibilitas, berpikir kreatif, kemampuan mengelola konflik, mengelola informasi dan sumberdaya, serta kapasitas untuk melakukan refleksi juga di harapkan dari para pekerja masa depan. Perubahan karakteristik dunia kerja ini memberi tantangan secara terus-menerus pada dunia pendidikan (terlebih pendidikan kejuruan yaitu SMK).

Di SMK, keterampilan generik lebih ditekankan pada pengembangan karier dan adaptasi terhadap perkembangan yang terjadi di dunia kerja. Pelaksanaan pembelajaran keterampilan generik dilakukan dengan pembuatan paket pembalajaran keterampilan generik (dalam hal ini perangkat pembelajaran yang berupa RPP, hand out, media pembelajaran power point, buku panduan dan perangkat evaluasi) yang pelaksanaannya disisipkan atau diintegrasikan pada mata pelajaran.

Salah satu keterampilan generik yang dibutuhkan di SMK adalah keterampilan generik komunikasi. Menurut Park, ManGon et al (2009, p.230) keterampilan generik komunikasi adalah suatu kemampuan berkomunikasi yang efektif dengan orang lain, dengan menggunakan lisan, tertulis, grafik, dan sarana non verbal lainnya seperti ekspresi. Lebih lanjut disebutkan oleh Rue dan Byars (2000, p.46) bahwa keterampilan komunikasi adalah keterampilan yang penting dan urgen dikuasai oleh seorang manager dan wirausaha, karena pada setiap fungsi misalnya managemen perencanaan, pengorganisasian, kekaryawanan, kepememimpinan dan pengontrolan, semuanya membutuhkan keterampilan komunikasi yang baik. Hal ini dikarenakan tujan akhir dari keterampilan komunikasi yang efektif dalam berwirausaha adalah untuk mendapatkan keuntungan bagi bisnis, sehingga dapat tercapai transformasi dan akselerasi bisnis ke tingkat yang lebih tinggi.

Senada dengan dua pendapat di atas, dipaparkan fakta riset (Robbins, 1996, p.4) yang menyatakan setiap individu menghabiskan hampir 70\% dari jam meleknya untuk berkomunikasi (menulis, membaca, berbicara, mendengarkan). Hal ini mengindikasikan bahwa: (1) salah satu kekuatan yang paling menghambat kesuksesan kinerja kelompok adalah kurangnya komunikasi yang efektif; (2) tidak ada kelompok yang eksis tanpa komunikasi: pentransferan makna diantara angotanya; (3) komunikasi harus mencakup pentansferan dan pemahaman makna.

Lebih lanjut dijelaskan, fungsi utama komunikasi dalam suatu kelompok atau organisasi adalah (1) kendali (kontrol, pengawasan); (2) motivasi; (3) pengungkapan emosional; dan (4) informasi (Robbins, 1996, p.5). Yang dimaksud dengan fungsi kendali adalah komunikasi bertindak untuk mengendalikan perilaku anggota misalnya perintah dari atasan kepada bawahan, karyawan diminta mengkomunikasikan setiap keluahan yang berkaitan dengan pekerjaan kepada atasan 
langsung, sedangkan fungsi terakhir yaitu informasi, hal ini berhubungan dengan peran komunikasi dalam mempermudah pengambilan keputusan.

Komunikasi memberikan informasi yang diperlukan individu dan kelompok untuk mengambil keputusan dengan meneruskan data guna mengenali dan menilai pilihan-pilihan alternatif. Inilah fungsi komunikasi dalam sebuah organisasi. Ketika sebuah organisasi bertujuan untuk berkinerja efektif, maka ia harus mempertahankan ragam kontrol terhadap anggotanya, merangsang para anggota untuk berkinerja, menyediakan sarana untuk pengungkapan emosi, dan mengambil keputusan.

Manusia selalu dihadapkan pada problem hidup yang harus dipecahkan dengan menggunakan berbagai sarana, keterampilan dan situasi yang dimanfaatkan. Kemampuan seperti itulah yang merupakan salah satu inti dari keterampilan generik yaitu keterampilan yang selalu diperlukan oleh seseorang dimanapun berada, baik berstatus peserta didik, pekerja, guru, pedagang maupun calon wirausaha. Salah satu keterampilan generik komunikasi yang dibutuhkan dan penting dikuasai dalam berwirausaha adalah keterampilan bernegosiasi. Menurut Fells (2009, p.3) negosiasi adalah proses dimana dua atau lebih kelompok yang mempunyai kepentingan yang sama atau berbeda berkumpul bersama untuk pencapaian kesepakatan.

Dalam dunia usaha/industri, negosiasi adalah cara terbaik dalam penyelesaian atau mencari jalan keluar ketika terjadi masalah dua pihak yang berbeda kepentingan dan kebutuhan dalam mendapatkan kesepakatan usaha. Hal ini karena bagi wirausaha negosisasi lebih dari sekedar diskusi mengenai keluhan-keluhan karyawan atau mitra kerja, masalah pengupahan, pengaturan senioritas dan sebagainya, akan tetapi negosiasi adalah perumusan atau kesepakatan bersama yang demokratis dari "peraturan kerja" dan "kondisi kerja" atas segala hal yang secara langsung berdampak pada para pekerja di tempat kerjanya. Dengan kata lain, negosiasi adalah dalam operasinya, merupakan pemerintahan sendiri. Negosiasi adalah suatu proses diterapkannya hukum-hukum di pabrik atau tempat kerja atas dasar persetujuan bersama.
Pengintegrasian keterampilan generik komunikasi khususnya bernegosiasi dalam pembelajaran di SMK akan memberikan bekal bagi peserta didik untuk memiliki kemampuan dan kesiapan mental serta tanggap dalam perubahan kondisi yang akan dihadapi di dunia kerja. Kemampuan dan mental untuk mau dan berani menghadapi problema hidup dan kehidupan secara wajar tanpa merasa tertekan, kemudian secara proaktif, kreatif dan inovatif mencari, menemukan solusi sehingga mampu mengatasi permasalahan.

Berdasarkan permasalahan inilah, dapat disimpulkan bahwa pengintegrasian keterampilan generik komunikasi ke dalam mata pelajaran di SMK masih menjadi persoalan, sehingga membutuhkan suatu pengembangan terutama dalam pengembangan perangkat pembelajaran yang mampu mengaktifkan siswa secara maksimal. Pengembangan perangkat pembelajaran merupakan salah satu cara untuk menjadikan pembelajaran bermakna. Perangkat pembelajaran ini juga merupakan salah satu prinsip dasar dalam menerapkan pendekatan pendidikan berbasis kompetensi dan pelatihan yang telah berhasil meningkatkan kompetensi siswa dalam program pelatihan kerja (Blank, 1982: 11).

Perangkat pembelajaran sangat berperan dalam proses penyampaian informasi dan komunikasi antara pendidik atau guru kepada peserta didik atau siswa. Pembelajaran yang di dalamnya diintegrasikan keterampilan generik komunikasi memerlukan pengalaman bermakna. Dengan menggunakan perangkat pembelajaran yang tepat diharapkan pembelajaran menjadi lebih bermakna dan dengan pembelajaran yang bermakna ini diharapkan peserta didik menjadi lebih bersemangat, tertarik dan termotivasi untuk belajar dengan sungguh-sungguh sehingga seluruh keterampilan dapat dikuasai (baik keterampilan teknis maupun keterampilan generik).

Lebih lanjut, menurut pendapat para ahli seperti Blank (1982), Dharma (2013), Norita (2013) perangkat pembelajaran dapat memberikan manfaat antara lain: (1) pembelajaran akan lebih menarik perhatian peserta didik sehingga dapat menumbuhkan motivasi belajar; (2) bahan pembelajaran 
akan lebih jelas maknanya sehingga dapat lebih dipahami oleh peserta didik dan memungkinkan peserta didik menguasai tujuan pembelajaran lebih baik; (3) metode pengajaran akan lebih bervariasi, tidak hanya menggunakan komunikasi verbal dari pendidik; (4) pembelajaran akan lebih terorganisir; (5) memudahkan pendidik atau guru dalam menentukan dan mencapai tujuan pembelajaran. Sebagai contoh dengan menggunakan perangkat pembelajaran hand out atau media power point peserta didik dapat mengulangi bagian yang belum dipahami sesuai dengan kecepatan dan kemampuan belajar masing-masing. Oleh karena itu dengan menggunakan perangkat pembelajaran yang di dalamnya diitegrasikan keterampilan generik komunikasi, peserta didik menjadi lebih aktif dan termotivasi dalam belajar, sehingga penguasaan keterampilan teknis dan keterampilan non teknis (keterampilan generik komunikasi) menjadi lebih meningkat.

Pada faktanya dalam proses pembelajaran yang mengintegrasikan keterampilan generik komunikasi ke dalam pembelajaran masih belum banyak dikembangkan khususnya di SMKN 4 Surakarta Program Keahlian Tata Busana. Hal ini terbukti dari: (1) angka pelaksanaan kegiatan pembelajaran yang bertujuan untuk meningkatkan keterampilan generik komunikasi siswa tata busana masih rendah; (2) masih tingginya angka kesulitan pendidik dalam mengajukan masalah kontekstual untuk meningkatkan keterampilan generik komunikasi; (3) kurang tersedianya sumber dan cara mengemas pembelajaran untuk meningkatkan keterampilan generik komunikasi siswa tata busana. Dengan adanya fakta ini semakin menunjukkan bahwa penelitian pengembangan perangkat pembelajaran keterampilan generik komunikasi di SMK Program Keahlian Tata Busana menjadi suatu hal yang penting dilakukan.

\section{METODE PENELITIAN}

Penelitian ini menggunakan jenis penelitian dan pengembangan atau research and development. Produk yang dikembangkan dalam penelitian ini adalah perangkat pembelajaran keterampilan generik komunikasi bernegosiasi untuk siswa kelas X SMKN 4 Surakarta. Ber- dasarkan hasil survei lapangan dan wawancara dengan wakil kepala sekolah bidang kurikulum dan guru mata pelajaran ditemukan perangkat pembelajaran yang efektif diterapkan dan dibutuhkan untuk dikembangkan meliputi perangkat pembelajaran yang berupa rencana pelaksanaan pembelajaran, hand out, media pembelajaran power point (ppt), buku panduan dan perangkat evaluasi.

Prosedur pelaksanaan penelitian R\&D ini diformulasikan dengan penelitian pengembangan perangkat model siklus 4-D atau empat tahapan pengembangan. Menurut Thiagarajan, Semmel \& Semmel (1974, p.5) model pengembangan 4-D terdiri atas empat tahapan pengembangan yaitu: tahapan pendahuluan (define), tahapan perencanaan (design), tahapan pengembangan (develop), dan tahapan desiminasi (disseminate).

Tahap define mencakup kegiatan studi pustaka dan survey lapangan untuk keperluan identifikasi masalah dan need analysis, tahap design mencakup kegiatan perancangan produk awal, tahap develop mencakup kegiatan validasi pakar, revisi produk, ujicoba satu-satu dan kelompok kecil, sedangkan tahap disseminate mencakup kegiatan sosialisasi lapangan dan revisi produk akhir.

Tahap pendahuluan (define) merupakan tahap awal atau tahap persiapan dalam melakukan pengembangan. Hal yang dilakukan pada tahap ini adalah studi pustaka dan survei lapangan. Survei lapangan dilakukan dengan tujuanuntukmemperoleh datatentang perangkat pembelajaran yang digunakan oleh guru, strategi pembelajaran yang digunakan guru, pembelajaran yang dilakukan baik di dalam kelas maupun di luar kelas, dan keterampilan generik yang dimiliki siswa. Survey lapangan ini dilakukan dengan observasi kelas yaitu ketika guru sedang mengajar di dalam kelas. Hal ini dimaksudkan untuk mengetahui proses yang dilakukan guru dan melihat bagaimana karakteristik siswa dalam mengikuti proses pembelajaran serta maksud yang lebih urgen lagi adalah mengidentifikasi masalah, dimana dari identifikasi masalah inilah ditemukan unsur-unsur yang akan dikembangkan.

Pada tahap studi pustaka, yang dilakukan adalah pengkajian terhadap konsep-konsep 
atau teori-teori yang berhubungan dengan perangkat pembelajaran yang akan dikembangkan dan strategi pembelajaran keterampilan generik dalam sebuah pembelajaran di SMK. Kajian yang dilakukan meliputi kajian terhadap kurikulum 2013 untuk kelas X SMK Program studi Keahlian Tata Busana. Hal yang perlu dilihat di dalam kurikulum ini adalah tujuan pembelajaran, karakteristik pembelajaran kelas $\mathrm{X}$, standar kompetensi lulusan, kompetensi inti, kompetensi dasar dan materi-materi pembelajaran, yang nantinya akan dimasukkan di dalamnya materi/konsep yang bisa menanamkan dan meningkatkan keterampilan generik komunikasi siswa.

Selain itu juga dilakukan kajian tentang hasil penelitian yang relevan dengan pengembangan perangkat pembelajaran keterampilan generik dan kajian pustaka tentang teori keterampilan generik. Setelah data-data yang diperlukan terkumpul, data tersebut dianalisis dengan menggunakan analisis deskriptif. Hasil analisis tersebut digunakan sebagai bahan untuk merancang desain pengembangan perangkat pembelajaran keterampilan generik komunikasi siswa SMK Program Studi Keahlian Tata Busana.

Langkah-langkah yang dilakukan pada tahap pendahuluan (devine) yang berupa analisis kebutuhan, yaitu: (1) analisis awalakhir (front-end analysis); (2) analisis siswa (learner analysis); (3) analisis konsep (concept analysis); (4) analisis tugas (task analysis); dan (5) tujuan instruksional khusus (specifying intructional objectives).

Sebagai tindak lanjut dari informasi yang diperoleh dari kegiatan pertama (define), kegiatan yang dilakukan berikutnya adalah merancang (design) pengembangan perangkat pembelajaran keterampilan generik komunikasi agar sesuai dengan kualifikasi yang dibutuhkan dunia kerja. Pada tahap perencanaan atau design ini dibuat perangkat pembelajaran yang berupa Rencana Pelaksanaan Pembelajaran (RPP), hand out siswa,media pembelajaran power point (ppt), buku panduan dan perangkat evaluasi.

Desain perangkat pembelajaran dikonsultasikan kepada pakar atau praktisi pendidikan kejuruan, pakar pendidikan tata busana dan guru mata pelajaran. Dengan demikian, pada tahap ini dihasilkan suatu rancangan model pengembangan perangkat pembelajaran keterampilan generik komunikasi, rancangan instrumen, dan pedoman atau panduan pengembangan perangkat pembelajaran keterampilan generik yang terintegrasi dalam pembelajaran.

Tahap pengembangan (develop), kegiatan yang dilakukan meliputi penyusunan instrumen dan pengembangan perangkat pembelajaran keterampilan generik, validasi pakar, uji coba terbatas, evaluasi dan revisi. Untuk lebih rincinya tahap ini diawali dengan menyusun naskah awal (draft) perangkat pembelajaran dari analisis kebutuhan pada studi lapangan sebelum pengembangan. Kemudian disusun perangkat pembelajaran awal dengan berpedoman pada kriteria penyusunan perangkat pembelajaran pada kajian teori.

Tahap berikutnya adalah tahap validasi perangkat dan instrumen melalui diskusi triangulasi (expert appraisal) dan tes pengembangan melalui tahap ujicoba awal (development testing). Pada tahap triangulasi (expert appraisal), peneliti melakukan diskusi dengan dosen dan guru untuk mengevaluasi kesesuaian perangkat pembelajaran dan instrumen yang disusun. Adapun evaluasi menyangkut isi materi, format, dan cara penyajian, sehingga diperoleh validasi isi. Berdasarkan hasil evaluasi, saran dan masukan dari dosen dan guru langkah selanjutnya adalah dilakukan revisi perangkat dan instrumen sebelum diujicobakan pada kelas sesungguhnya.

Pada tahap desiminasi, perangkat pembelajaran yang telah dibuat diujicobakan melalui penerapan perangkat pada kelas sesungguhnya (secara terbatas atau ujicoba kelompok kecil). Hasil ujicoba dianalisis untuk menentukan validitas perangkat (validitas empirik). Berdasarkan ujicoba akan diketahui kekurangan dari perangkat yang disusun dan selanjutnya dijadikan sebagai suatu acuan penyusunan produk jadi yang lebih layak digunakan dalam proses pembelajaran. Perangkat pembelajaran yang telah disusun (setelah memalui proses revisi), selanjutnya diujicobakan di kelas sesungguhnya (uji coba lapangan atau field trial). Berikut prosedur pengembangan dan desain uji coba berdasarkan metode $4 \mathrm{D}$. 


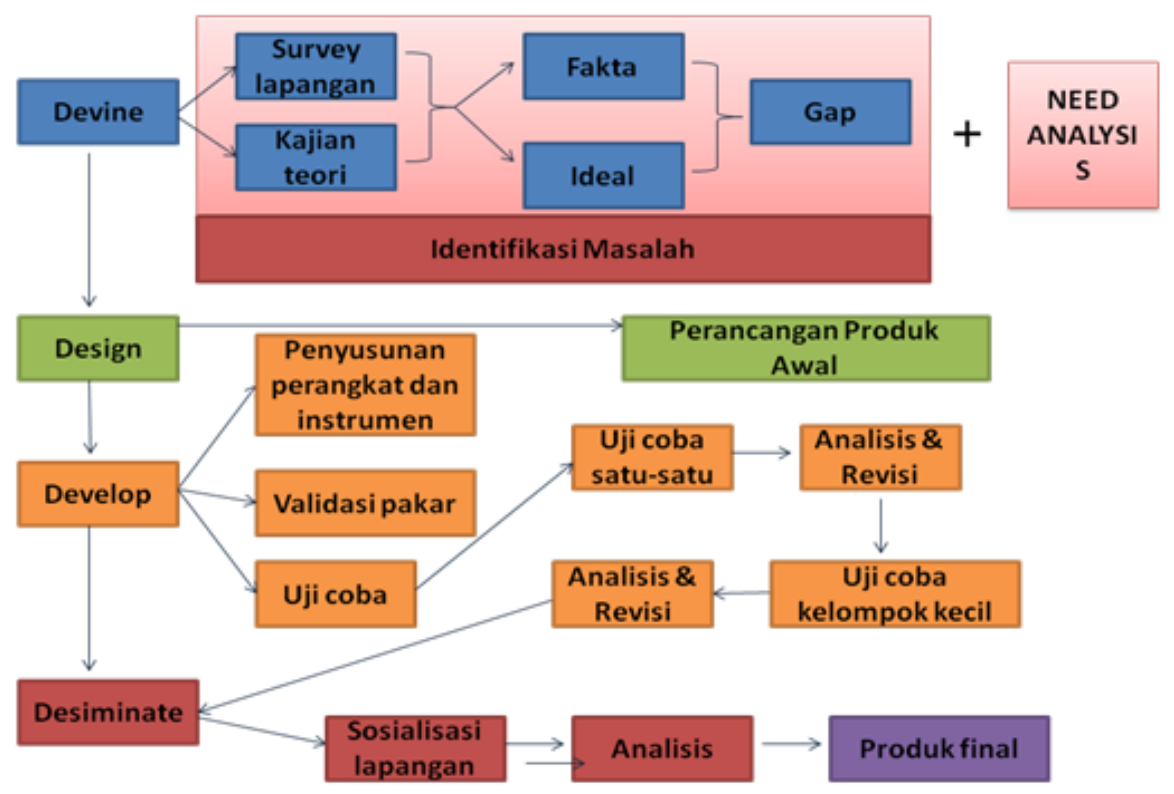

Gambar 1. Tahap pengembangan dan uji coba

Penelitian melibatkan subyek coba siswa kelas X SMKN 4 Surakarta Program Keahlian Tata Busana. Adapun jumlah subyek coba secara keseluruhan adalah 41 siswa, dengan rincian yaitu: (1) memilih secara random siswa kelas X Program Studi Keahlian Tata Busana SMK Negeri 4 Surakarta yang dapat mewakili populasi sebanyak 3 orang siswa untuk ujicoba satu-satu (one to one evaluation); (2) 6 orang siswa (tidak termasuk siswa pada ujicoba satusatu atau one to one evaluation) untuk ujicoba kelompok kecil (small group evaluation); (3) 32 orang siswa (tidak termasuk siswa pada ujicoba kelompok kecil) untuk ujicoba lapangan (field trial).

Adapun pakar (expert) dan guru yang dilibatkan pada penelitian ini berjumlah 2 orang pakar dan 1 orang guru, dengan rincian sebaga berikut: (1) 2 orang pakar yang dilibatkan dalam penelitian ini adalah dua orang yang pakar dibidang pendidikan teknologi kejuruan, pakar media atau perangkat pembelajaran dan pakar kewirausahaan; dan (2) satu orang guru yang terlibat dalam penelitian ini adalah guru pembelajaran bidang tata busana yang bertugas sebagai pengajar, pengamat, validator dalam uji coba untuk melihat keterlaksanaan perangkat pembelajaran keterampilan generik yang sudah dikembangkan.
Teknik pengumpulan data pada penelitian ini digunakan untuk menetapkan kualitas dan kelayakan produk perangkat pembelajaran yang dikembangkan. Adapun teknik pengumpulan yang digunakan pada penelitian ini adalah: (1) tahap pendahuluan: menggunakan teknik pengumpulan data observasi, dokumentasi, dan wawancara. Secara umum, ketiga teknik tersebut digunakan secara bersamaan dan saling melengkapi; (2) tahap perencanaan: menggunakan teknik pengumpulan data observasi, dokumentasi, wawancara dan kajian literatur. Secara umum, semua teknik tersebut digunakan secara bersamaan dan saling melengkapi; (3) tahap pengembangan: teknik pengumpulan data yang digunakan pada tahap pengembangan produk awal adalah menggunakan validasi instrumen, sedangkan pada tahap uji coba satu-satu dan uji coba kelompok kecil teknik pengumpulan data yang digunakan adalah observasi dan angket; dan (4) tahap desiminasi: teknik pengumpulan data yang digunakan pada tahap ini adalah angket, observasi, dan penilaian keterterapan.

Teknik analisis data penelitian ini menggunakan teknik analsis deskriptif secara kualtatif dan secara kuantitatif. Teknik analisis deskriptif secara kualitatif digunakan untuk mendeskripsikan tahapan pengembangan yang 
menggambarkan hasil pengamatan keterlaksanaan pengembangan perangkat pembelajaran keterampilan generik dan keterlaksanaan atau keefektifan perangkat pembelajaran keterampilan generik yang sudah dikembangkan di lapangan.

Analisis data secara kuantitatif ini digunakan pada tahap pengembangan dan desiminasi. Pendekatan analisis data yang digunakan adalah: (1) pelaksanaan dan hasil pengembangan perangkat pembelajaran keterampilan generik dan validitas perangkat pembelajaran keterampilan generik dideskripsikan dalam bentuk sajian data, kemudian dianalisis secara kualitatif dan kuantitatif; (2) pada uji coba satu-satu dan ujicoba kelompok kecil, hasil ujicoba penerapan perangkat pembelajaran keterampilan generik dianalisis dengan pendekatan kuantitatif; (3) pada ujicoba lapangan menggu-nakan pendekatan analisis kuantitatif.

Berikut ini langkah-langkah yang digunakan untuk memenuhi kriteria kualitas terhadap produk perangkat pembelajaran yang dikembangkan adalah: (1) data berupa skor ahli atau pakar (expert) yang diperoleh melalui lembar validasi dijumlahkan; (2) total skor aktual yang diperoleh kemudian dikonversikan menjadi data kualitatif skala empat seperti yang ditunjukkan pada tabel 1 .

Tabel 1. Konversi Data Kuantitatif ke Kualitatif Skala 4

$3,5 \leq \mathrm{M} \leq 4,5 \rightarrow$ kategori $\rightarrow$ sangat baik

$2,5 \leq \mathrm{M} \leq 3,5 \rightarrow$ kategori $\rightarrow$ baik

$1,5 \leq \mathrm{M}<2,5 \rightarrow$ kategori $\rightarrow$ kurang baik

$0,5 \leq \mathrm{M}<1,5 \rightarrow$ kategori $\rightarrow$ tidak baik

$\mathrm{M}=$ Rerata skor untuk setiap aspek yang dinilai

(Sumber: Saifuddin Azwar, 2012, p.149)

Adapun mengenai teknik analisis untuk mengukur kevalidan perangkat pembelajaran keterampilan generik komunikasi, baik itu berupa perangkat pembelajaran seperti RPP, hand out, power point, buku panduan, perangkat evaluasi pembelajaran maupun yang berupa instrumen-instrumen yang dikembangkan seperti format-format validasi dan instrumeninstrumen yang akan divalidasi, diberikan kepada pakar (expert) yang dipandang layak untuk memberikan penilaian terhadap aspekaspek yang tercantum dalam perangkat terse- but. Aspek yang dinilai pada umumnya terdiri dari aspek petunjuk, aspek isi/cakupan dan aspek bahasa. Adapun indikator kevalidan perangkat pembelajaran baik validitas isi maupun validitas konstruk pada penelitian ini mengacu pada kriteria Nieveen (1999, p.126). Kategori validitas setiap aspek atau keseluruhan aspek yang dinilai ditetapkan berdasarkan kriteria pengkategorian kualitas perangkat yang diadaptasi dari pengkategorian sesuai tabel 1 .

Kriteria yang digunakan untuk memutuskan bahwa instrumen memiliki derajat validitas yang memadai adalah apabila rerata (M) hasil penilaian untuk keseluruhan aspek minimal berada dalam kategori "valid". Apabila tidak demikian, maka perlu dilakukan revisi berdasarkan saran para validator atau dengan melihat kembali aspek-aspek yang nilainya kurang. Selanjutnya dilakukan validasi ulang kemudian dianalisis kembali. Demikian seterusnya sampai memenuhi nilai rerata minimal berada dalam kategori valid. Secara umum rerata skor dianalisis dengan menggunakan program excel dan penilaian antara rater menggunakan SPSS.

Selanjutnya untuk mengukur tingkat kesepahaman antar penilai (inter rater reability) terhadap hasil penilaian/validasi instrumen penelitian oleh para ahli (expert), dianalisis dengan statistik coeffisien cohen's kappa dan percentage of agreement dari Nitko dan Brokhatr (2007, p.80). Lembar penilaian perangkat pembelajaran dikatakan reliabel jika koefisien reliabilitasnya $(\mathrm{R}) \geq 0,7$.

Analisis data kepraktisan perangkat pembelajaran keterampilan generik komunikasi, dikatakan praktis apabila menurut penilaian ahli (expert) dan guru pengajar mata pelajaran menyatakan bahwa perangkat pembelajaran keterampilan generik komunikasi yang dikembangkan praktis dan dapat diterapkan di sekolah. Perangkat pembelajaran keterampilan generik komunikasi dikatakan memenuhi kepraktisan apabila: (1) menurut penilaian ahli (expert) dan praktisi (guru) menyatakan bahwa perangkat pembelajaran keterampilan generik komunikasi dapat diterapkan dengan minimal revisi kecil; dan (2) secara nyata di lapangan dapat diterapkan untuk semua aspek teramati termasuk dalam kategori terlaksana. 
Perangkat pembelajaran keterampilan generik komunikasi dikatakan efektif apabila memenuhi empat indikator keefektifan yaitu: (1) aktivitas siswa dalam pembelajaran adalah perilaku yang diperlihatkan oleh siswa pada saat mengikuti proses pembelajaran dalam kategori baik; (2) respon siswa terhadap penerapan perangkat pembelajaran keterampilan generik komunikasi adalah minimal responnya positif; (3) respon guru terhadap penerapan perangkat pembelajaran keterampilan generik komunikasi adalah minimal responnya positif dan secara objektif guru mengatakan bahwa perangkat pembelajaran keterampilan generik komunikasi dapat digunakan untuk menumbuhkan keterampilan generik komunikasi siswa SMK; (4) pencapaian kompetensi belajar siswa secara klasikal mencapai kategori tuntas; dan (5) penilaian kesesuain perangkat pembelajaran yang dikembangkan dengan need analisys dinyatakan minimal dalam kategori sesuai oleh pakar (expert).

Adapun langkah-langkah analisis data terhadap keefektifan perangkat pembelajaran keterampilan generik dalam hal pencapaian kompetensi belajar siswa ini adalah: (1) menghitung skor setiap siswa (SI), skor siswa dalam kelompok (SK) dan skor presentasi siswa (SP); (2) menghitung frekuensi atau nilai siswa yang mencapai tingkat hasil belajar yang ditentukan (kriteria ketuntasan minimal atau KKM) yaitu: 70 (nilai KKM SMKN 4 Surakarta); dan (3) menentukan ketercapaian tujuan atau hasil belajar secara klasikal (seluruh siswa dalam satu kelas) yaitu 75\% siswa mencapai KKM.

Hasil kinerja siswa diperiksa dan dinilai berdasarkan pedoman penskoran. Nilai maksimal untuk hasil belajar adalah 100. Hasil belajar dikatakan efektif secara individual jika kemampuan siswa dalam menguasai dan menggunakan keterampilan generik komunikasi dalam berbagai situasi mencapai skor KKM 70, sedangkan hasil belajar siswa dikatakan efektif secara klasikal jika paling sedikit $75 \%$ siswa subyek uji coba (dalam satu kelas) mencapai kriteria ketuntasan individual.

\section{HASIL PENELITIAN DAN PEMBAHASAN}

Berdasarkan hasil penelitian pada tahap define ditemukan bahwa perangkat pembel- ajaran yang dibutuhkan dan penting untuk dikembangkan oleh SMKN 4 Surakarta untuk mengajarkan dan melatihkan keterampilan generik komunikasi, guna menyiapkan tenaga kerja masa depan yang mampu menjawab tren dan tantangan global adalah RPP, hand out, media pembelajaran power point, buku panduan dan perangkat evaluasi. Hasil ini diperoleh dari kegiatan pokok yang dilaksanakan pada tahap define yaitu identifikasi masalah dan analisis kebutuhan yang dilaksanakan dengan cara melakukan survei lapangan dan studi pustaka.

Survei lapangan dilakukan untuk mengumpulkan informasi dan melakukan analisis kebutuhan perangkat pembelajaran yang akan dikembangkan. Untuk memperoleh data tentang perangkat pembelajaran yang dibutuhkan, maka dilakukan wawancara dan observasi untuk mengungkap perangkat pembelajaran yang digunakan di SMK, strategi pembelajaran yang digunakan guru, pembelajaran kewirausahaan yang dilakukan baik di dalam kelas maupun di luar kelas, dan keterampilan generik yang dimiliki siswa. Sedangkan tahap studi pustaka, dilakukan untuk memperoleh informasi tentang konsep-konsep, teori-teori atau strategi pembelajaran yang relevan dan mendukung dalam pengembangan perangkat pembelajaran keterampilan generik dalam mata pelajaran prakarya dan kewirausahaan. Setelah data-data yang diperlukan terkumpul (data hasil analisis kebutuhan dan hasil studi pustaka), data tersebut dianalisis dengan menggunakan analisis deskriptif.

Berikutnya, dilakukan kajian yang lebih mendalam untuk memperoleh informasi tentang pembelajaran keterampilan generik komunikasi, perbedaan perkembangan dan kemampuan belajar siswa, teori dan strategi pembelajaran yang relevan, pendekatan pembelajaran, metode penelitian dan pengembangan perangkat pembelajaran dan metode 4D, serta seluruh informasi lainnya yang berhubungan dengan pengembangan perangkat pembelajaran keterampilan generik komunkasi menggunakan metode 4D. Selanjutnya, hasil kajian ini digunakan untuk melakukan perencanaan pengembangan perangkat pembelajaran.

Dari hasil analisis kebutuhan kompetensi dan kebutuhan pembelajaran pada tahap de- 

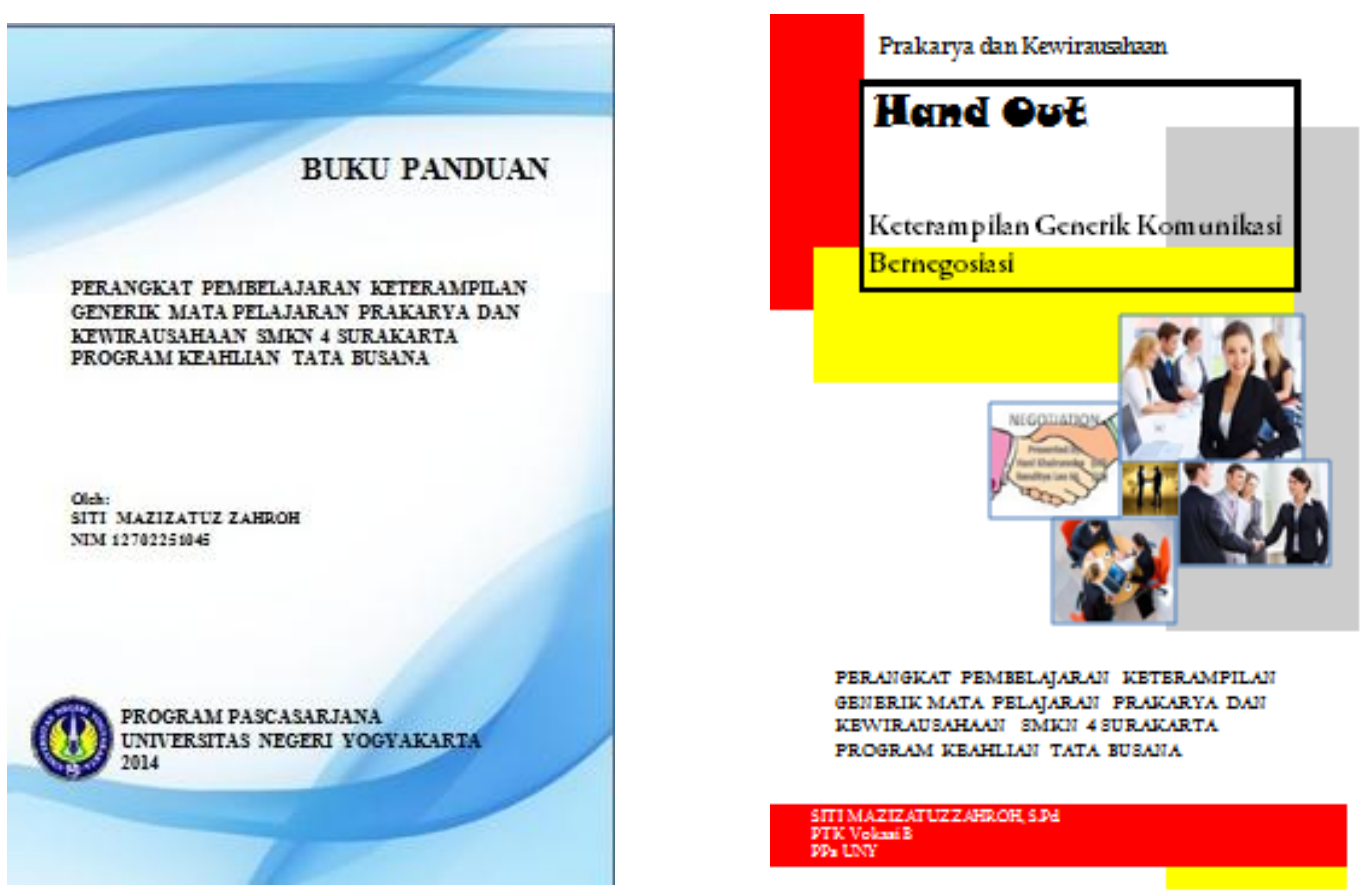

Gambar 2. Produk awal buku panduan dan hand out

fine, selanjutnya menjadi dasar perancangan pengembangan (design). Perancangan pengem bangan (design) meliputi pemilihan strategi pembelajaran dan perancangan produk awal. Strategi pembelajaran yang diintegrasikan ke dalamnya keterampilan generik komunikasi pada penelitian ini adalah menggunakan pendekatan collaborative learning (CL) tipe JIGSAW dan pendekatan problem based learning (PBL) yang merupakan konsep belajar berkelompok dan berpusat pada siswa, sehingga siswa dituntut untuk merekonstruk-sikan pengetahuannya secara mandiri. Pembelajaran kooperatif atau cooperative learning tipe JIGSAW dalam penelitian ini terdapat beberapa aktivitas pendekatan pembelajaran di antaranya: contructivism, inquiry, questioning, learning community, modeling, pembuatan laporan dan reflection.

Semua komponen yang telah disusun di atas menjadi bahan acuan untuk membuat rancangan produk awal. Rancangan produk awal yang diwujudkan dalam bentuk: buku panduan dan perangkat pembelajaran (seperti RPP, hand out, power point, perangkat evaluasi) serta instrumen-instrumen penelitian (seperti instrumen pengamatan perilaku siswa dalam pembelajaran, instrumen keefektifan perangkat pembelajaran, instrumen kepraktisan perangkat pembelajaran, instrumen keterlaksanaan perangkat pembelajaran). Berikut hasil perancangan produk awal perangkat pembelajaran keterampilan generik komunikasi negosiasi.

Berdasarkan hasil penelitian pada tahap design, secara keseluruhan menunjukkan bahwa desain perangkat pembelajaran yang dikembangkan yang terkandung di dalamnya keterampilan generik komunikasi adalah desain struktur atau konstruk materi perangkat pembelajaran yang tersusun secara sistematis, menggunakan bahasa yang mudah dipahami, cakupan materi yang mampu memberikan gambaran yang jelas tentang keterampilan generik komunikasi bernegosiasi, serta konten tugas (baik tugas individu maupun tugas kelompok) yang mampu melatih keterampilan generik komunikasi bernegosiasi siswa SMK.

Adapun hasil penelitian pada tahap develop menunjukkan bahwa metode 4D merupakan metode yang fisibel dan efektif untuk digunakan dalam mengembangkan perangkat pembelajaran keterampilan generik komunikasi. Hal ini karena dalam metode 4D terdapat tahapantahapan yang sistematis dan mendukung dalam terciptanya perangkat pembelajaran yang baik dan layak digunakan dalam pembelajaran. 
Tabel 2. Hasil validasi ahli

\begin{tabular}{ccccccccccc}
\hline \multirow{2}{*}{ Validator } & \multicolumn{2}{c}{ RPP } & \multicolumn{2}{c}{ Hand Out } & \multicolumn{2}{c}{ Power Point } & \multicolumn{2}{c}{ Buku Panduan } & \multicolumn{2}{c}{$\begin{array}{c}\text { Perangkat } \\
\text { Evaluasi }\end{array}$} \\
\cline { 2 - 10 } & Skor & Kriteria & Skor & Kriteria & Skor & Kriteria & Skor & Kriteria & Skor & Kriteria \\
\hline 1 & 4 & SV & 4 & SV & 4 & SV & 4 & SV & 4 & SV \\
2 & 3 & V & 3 & V & 4 & SV & 3 & V & 3 & V \\
3 & 4 & SV & 4 & SV & 4 & SV & 4 & SV & 4 & SV \\
\hline Rerata & 3,67 & SV & 3,67 & SV & 4 & SV & 3,67 & SV & 3,67 & SV \\
\hline
\end{tabular}

Keterangan:

$\mathrm{V}=$ Valid

$\mathrm{SV}=$ Sangat Valid

Tabel 3. Hasil analisis statistik

\begin{tabular}{lllll}
\hline No & Nama Produk Pengembangan & $\begin{array}{c}\text { Koefisien } \\
\text { Reliabilitas }\end{array}$ & Kriteria & Kategori \\
\hline 1 & Rencana Pelaksanaan Pembelajaran (RPP) & 0,783 & $\geq 0,70$ & Reliabel \\
2 & Hand out & 0,750 & $\geq 0,70$ & Reliabel \\
3 & Power point & 0,865 & $\geq 0,70$ & Reliabel \\
4 & Buku panduan & 0,800 & $\geq 0,70$ & Reliabel \\
5 & Perangkat evaluasi & 0,744 & $\geq 0,70$ & Reliabel \\
\hline
\end{tabular}

Hasil penelitian pada tahap develop ini juga didukung dengan data hasil validasi oleh para ahli (expert) yang menunjukkan bahwa perangkat pembelajaran yang dihasilkan dengan menggunkan metode 4D layak untuk digunakan pada pembelajaran di SMK. Berikut hasil data validasi para ahli.

Berdasarkan hasil data di atas menunjukkan bahwa semua validator (baik ahli media maupun ahli materi) menyatakan bahwa perangkat pembelajaran keterampilan generik komunikasi dapat digunakan dalam pembelajaran di SMK dengan perolehan rata-rata hitung sebesar 3,74 (pada kategori sangat valid).Berikutnya, data yang diperoleh (data hasil validasi para ahli) diukur tingkat kesepahaman antar penilai/validator (inter rater reability) terhadap hasil penilaian/validasi produk penelitian. Untuk mengukur tingkat kesepahaman antara dua ahli ini digunakan teknik analisis statistik coeffisien cohen's kappa dengan SPSS. Berikut hasil analisis statistik coeffisien cohen's kappa untuk setiap produk yang dihasilkan.

Berdasarkan hasil analisis statistik diperoleh suatu kesimpulan bahwa produk pengembangan yang dihasilkan dinyatakan sangat valid dengan tingkat kesepahaman antar validator $=$ tinggi yaitu semua produk atau perangkat pem- belajaran yang dikembangkan mencapai angka $\geq 0,7$. Dengan demikian, perangkat pembelajaran yang dihasilkan memenuhi kriteria valid dan reliabel untuk dipergunakan dalam pembelajaran SMK.

Adapun hasil penelitian pada tahap disseminate menunjukkan bahwa perangkat pembelajaran keterampilan generik komunikasi negosiasi yang dihasilkan dengan metode 4D memenuhi kriteria valid dan praktis untuk diterapkan di SMK. Untuk perolehan kriteria efektif ini tergambar dari: (1) terpenuhinya standar ketuntasan belajar siswa secara individu dan secara klasikal yaitu $100 \%$ siswa tuntas (mendapat nilai $\geq 75$ yaitu siswa $100 \%$ mendapat nilai di atas nilai rata-rata 89,05); (2) aktivitas siswa dalam pembelajaran atau perilaku yang diperlihatkan oleh siswa pada saat mengikuti proses pembelajaran dalam kategori sangat baik; (3) respon yang diberikan siswa terhadap penerapan perangkat pembelajaran keterampilan generik komunikasi adalah respon positif yaitu mencapai skor 3,36 (kategori efektif), (4) respon yang diberikan guru terhadap penerapan perangkat pembelajaran keterampilan generik komunikasi adalah respon positif yaitu mencapai skor 3,06, (5) secara objektif guru dan ahli mengatakan bahwa perang- 


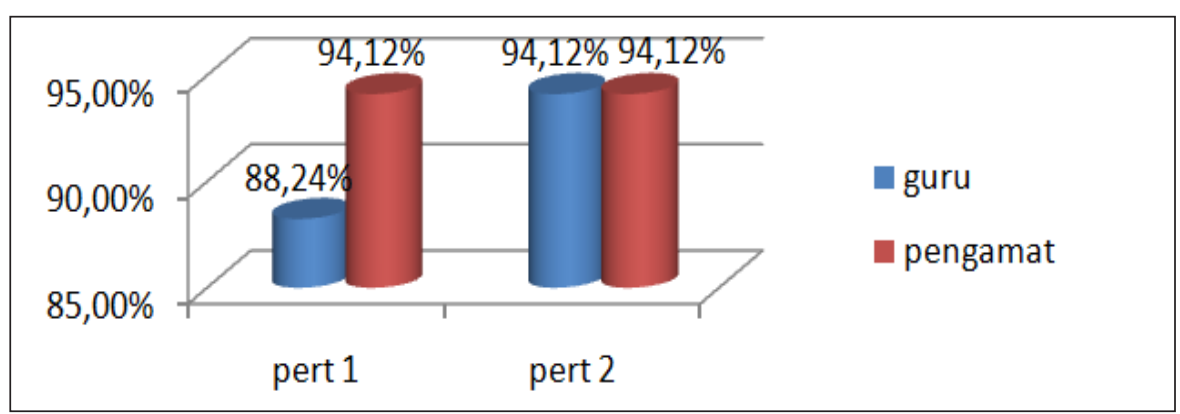

Gambar 2. Hasil analisis data keterlaksanaan perangkat

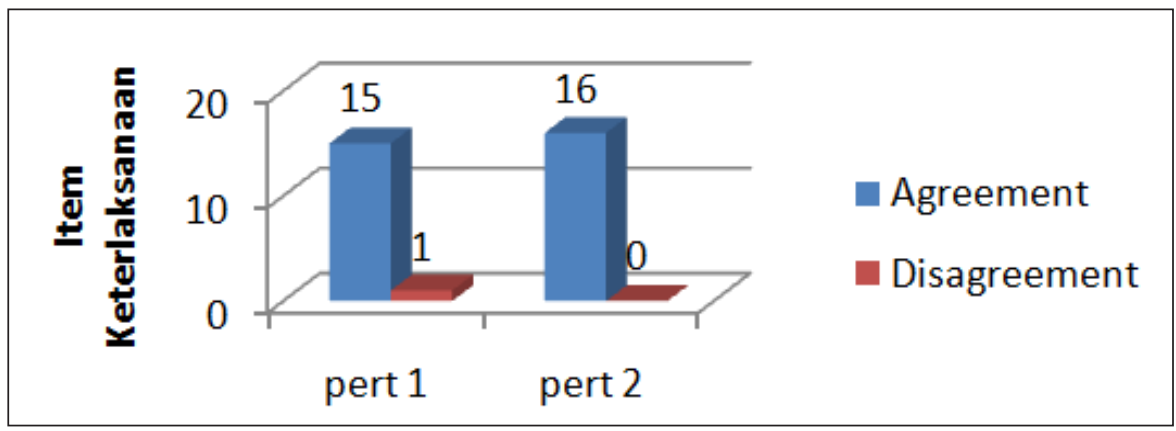

Gambar 3 Hasil analisis percentage agreement keterlaksanaan perangkat

kat pembelajaran keterampilan generik komunikasi sesuai dengan need analisys dan dapat digunakan untuk menumbuhkan dan melatih keterampilan generik komunikasi siswa SMK.

Untuk perolehan kriteria praktis dapat tergambar dari: (1) hasil analisis kepraktisan perangkat pembelajaran yang diukur dari penilaian guru dan siswa, pengamatan perilaku siswa, pengamatan keterlaksanaan perangkat oleh guru dan pengamat, secara keseluruhan memenuhi kriteria sangat baik dengan rata-rata tingkat keterlaksanaan $88,18 \%$; dan (2) hasil analisis realibilitas antar pengamat dengan menggunakan percentage agreement dari Nitko dan Brookhart (2011: 80) yang menunjukkan bahwa hasil pengamatan terhadap keterlaksanaan perangkat pembelajaran keterampilan generik menunjukkan rata-rata percentage agreement adalah sangat tinggi yaitu $94 \%$ pada pertemuan pertama dan $100 \%$ pada pertemuan kedua, sehingga jika dirata-rata didapatkan tingkat keterlaksanaan perangkat pada pembelajaran sebesar $97 \%$. Hasil analisis tersebut menunjukkan bahwa kedua pengamat memiliki persepsi pemahaman yang sama bahwa keterlaksanaan perangkat pembelajaran pada mata pelajaran prakarya dan kewirausahaan telah terlaksana dengan sangat baik dan sesuai dengan yang diharapkan yaitu dengan tingkat keajegan yang tinggi. Berikut hasil analisis data keterlak-sanaan perangkat dan hasil analisis percentage agreement keterlaksanaan perangkat dalam bentuk diagram batang.

\section{SIMPULAN DAN SARAN}

\section{Simpulan}

Berdasarkan hasil penelitian dan pembahasan dapat disimpulkan bahwa: (1) metode 4D merupakan metode yang fisibel dan efektif untuk digunakan dalam mengembangkan perangkat pembelajaran keterampilan generik komunikasi. Hal ini karena dalam metode 4D terdapat tahapan-tahapan yang sistematis dan mendukung dalam terciptanya perangkat pembelajaran yang baik dan layak digunakan dalam pembelajaran. Tahapan pengembangan perangkat tersebut adalah (a) tahap pendahuluan (define) meliputi prasurvei, survei lapangan, analisis, studi pustaka, analisis kebutuhan, konsultasi pakar; (b) tahapan perencanaan (design) meliputi konsultasi dosen, perancangan prototipe perangkat; (c) tahapan pengembangan (develop) meliputi penyusunan instrumen, pengembangan perangkat pembelajaran keterampilan generik, validasi pakar, revisi I, uji 
coba satu-satu (one to one evaluation), evaluasi dan revisi II; (d) tahapan desiminasi (desiminate) meliputi uji coba kelompok kecil (small group evaluation), evaluasi dan revisi III, uji coba lapangan (field trial), evaluasi dan revisi produk akhir. (2) perangkat pembelajaran yang dihasilkan mampu mengajarkan dan melatih keterampilan generik komunikasi bernegosiasi siswa kelas X SMKN 4 Surakarta.

\section{Saran}

Adapun saran yang diberikan dalam pemanfaatan produk atau perangkat pembelajaran keterampilan generik komunikasi bernegosiasi ini adalah: (1) perangkat pembelajaran yang dikembangkan ini telah teruji kelayakannya yaitu telah memenuhi kriteria valid, sehingga dapat digunakan dalam pembelajaran prakarya dan kewirausahaan. Akan tetapi dalam pengujian perangkat pembelajaran ini hanya sampai pada tahap uji coba lapangan pada satu kelas, sehingga disarankan kepada guru SMK untuk mengimplementasikan atau menerapkan di kelas X yang lain. (2) Penerapan perangkat pembelajaran keterampilan generik pada pembelajaran efektif memberikan motivasi dan semangat berkarya, berwirausaha dan berkomunikasi kepada siswa, sehingga disarankan kepada guru SMK agar menggunakan perangkat pembelajaran ini sebagai pendukung dalam pembelajaran di kelas. (3) Penerapan perangkat pembelajaran keterampilan generik komunikasi dapat terlaksana dengan sangat baik di kelas, sehingga dapat dikatakan perangkat ini praktis digunakan di sekolah. Oleh sebab itu, disarankan kepada guru agar menggunakan perangkat pembelajaran keterampilan generik komunikasi ini.

\section{DAFTAR PUSTAKA}

Azwar, Saifuddin. (2012). Reliabilitas dan validitas. Yogyakarta: Pustaka Belajar.

Blank, W.E. (1982). Handbook for developing competency based training programs. USA: Prentice-Hall, Inc.

Dharma, S. et al. (2013). Tantangan guru SMK abad 21. Jakarta: Direktorat Pembinaan Pendidikan dan Tenaga Kependidikan Pendidikan Menengah.
Fells, Ray. (2009). Effective negotiation from research to results. New York: Cambridge University Press.

Nieveen, Nienke. (1999). Protoptyping to reach product quality. In Jan Van den akker. RM, Branch, K. Gustafson, N, Nieveen \& Tj Plomp (Eds) Design approachess and tools in education and training (pp 125-135) Kluwer Academic Publishers, Drordrech, The Nederland.

Nitko, A.J., \& Brookhart, S.M. (2007). Educational assessment of students. New Jersey: Pearson Merril Prentice Hall.

Norita. (2013). Penerapan pembelajaran kooperatif menggunakan hand out untuk meningkatkan hasil belajar matematika siswa SMP Monterado. Artikel penelitian. Universitas Tanjungpura Pontianak.

Park, Man-Gon et al. (2009). Work, learning and sustainable development: opportunities and challenges. Sustainable development through a skilled, knowledgebased workforce. UNESCO-UNEVOC book series: technical and vocational education and training. Australia: Springer Science and Business Media B.V.

Robbins, S.P. (1996). Organizational behaviour: concepts, controversies, applications. New Jersey: Prentice Hall, Inc. Edisi terjemah: Perilaku organisasi: konsep, kontroversi, aplikasi. Jakarta: Prenhallindo.

Rue, L.W. \& Byars, L.L. (2000). Management skill and application. Nort America: McGraw-Hill Companies, Inc.

Suarta, I Made. (2012). Pengembangan konstruk sistem pembelajaran pada pendidikan vokasi. Jurnal pendidikan vokasi Vol.2 Nomor.1 Februari 2012. Yogyakarta: ADGVI.

Thiagarajan, S., Semmel, D.S. \& Semmel, M.I. (1974). Instructional development for training teachers of exceptional children. Bloomington: Indiana University. 